\title{
The classification and comparison of genetic diversity of genus Malus using RAPD
}

\author{
Man Kyu Huh* \\ Department of Molecular Biology, Dong-eui University \\ Received April 30, 2007/Accepted June 8, 2007
}

\begin{abstract}
Genus Malus is a long-lived woody species primarily distributed throughout Asia. Many species of this genus are regarded as agriculturally and ecologically important. The phynetics and genetic diversity among eight species of genus Malus were reconstructed using the random amplified polymorphic DNA (RAPD) markers. In a simple measure of intraspecies variability by the percentage of polymorphic bands, the $M$. micromalus exhibited the lowest variation (34.7\%). The M. pumila showed the highest $(50.0 \%)$. Mean number of alleles per locus $(A)$ ranged from 1.347 to 1.500 with a mean of 1.437. The phenotypic frequency of each band was calculated and used in estimating genetic diversity $(H)$ within species. The mean of $H$ was 0.190 across species, varying from 0.155 to 0.220 . In particular, two cultivated species, M. pumila and M. asiatica, had high expected diversity, 0.314 and 0.307 , respectively. On a per locus basis, the proportion of total genetic variation due to differences among species ranged from 0.388 to 0.472 with a mean of 0.423 , indicating that $42.3 \%$ of the total variation was found among species. The phylogenetic tree showed three distinct clades. One includes $M$. sieversii, $M$. pumila, and $M$. asiatica. Another includes three $M$. baccata taxa. The other includes $M$. sieboldii, $M$. floribunsa, and M. micromalus. One variety and one form of $M$. sieboldii were well separated each other. RAPD markers are useful in germ-plasm classification of genus Malus and evolutionary studies.
\end{abstract}

Key words - Genus Malus, RAPD, Phylogenetic relationships

\section{Introduction}

Malus (Miller), a genus of the family Rosaceae consists of diploid species $(2 n=34,51)$ and is mainly distributed in northeastern Asia [7]. Especially, Malus pumila Miller of the genus is economically important for its fruits (apples).

Apples are certainly among the earliest fruits to be gathered by people, and their domestication is probably preceeded by a long period of unintentional planting via rubbish dispersal. It is difficult to determine exactly when the apple was first domesticated, but the Greeks and Romans were growing apples at least 2,500 years ago [10]. The Romans spread the apple across Europe during their invasions and it was dispersed to the New World by European settlers during the 16th century.

Malus asiatica Nakai is distributed in northeastern China, Korea, and Japan. Asian regions such as China, Korea, Japan and Russia are well known for giving various Malus species [7]. The genus Malus is comprised of about eight taxa (six species, one variety, and one form)

\section{* Corresponding author}

Tel : +82-51-890-1529, Fax : +82-51-890-1521

E-mail : mkhuh@deu.ac.kr in Korea. The taxonomy of Malus has been processed mainly through morphological characteristics [15] and allozymes [4,21]. However, morphological characteristics are restricted their resolving powers because of the small number of available characters. Allozyme analysis is cost-effective and can be applied without extensive technical development and allozyme exhibit Mendelian inheritance. Nevertheless, there are several reasons to apply other types of markers. For instance, attempts to measure gene flow at small spatial scale by allozyme alleles are frequently frustrated by the limited variability of allozymes [2]. The development of molecular makers has provided powerful tools that may overcome such limitations. Random amplified polymorphic DNA (RAPD) analysis is quick, robust and requires minimal preliminary work [1]. Efficient methods to clarify the taxonomic status of several species are much needed [11].

The aims of this study were; 1 ) to estimate how much total genetic diversity is maintained in the Malus species, 2) to describe how genetic variation is distributed within and among species, and 3) to elucidate the suitability and efficiency of the RAPD analyses assess the phylogenetic relationships among the related Malus species in Korea. 


\section{Materials and Methods}

\section{Plant materials}

The plant materials were used the molecular studies of 88 samples representing nine species of Malus. Chaenomeles speciosa (Sweet) Nakai and Pyrus pyrifolia (Burm. fil) Nakai var. culta (Makino) Nakai were used as outgroups to compare the phylogenic relationships. Eight species of the genus Malus, M. asiatica, M. baccata, M. baccata var. mandshurica, M. baccata for. Minor, M. floribunda, M. micromalus, M. pumila, and M. sieboldii, were collected from populations in Korea (Table 1). Wild apple species, M. sieversii was obtained from the Korea Forest Research Institute. $M$. pumila and $M$. asiatica are cultivated species and other species are wild (natural) species. One young leaf per mature tree $(5 \mathrm{yr})$ was sampled. To analyze the proportion of genetic diversity among and within taxa, 100 plants were randomly collected from each taxon.

\section{DNA extraction and RAPD analysis}

The genomic DNA of all samples including the outgroup was extracted from fresh leaves using the plant DNA Zol Kit (Life Technologies Inc., Grand Island, New York, U.S.A.) according to the manufacturer's protocol. The DNA concentration of each sample was determined spectrometrically and was electrophoresed on a $0.8 \%$ agarose gel to confirm quality.

Forty arbitrarily chosen 10 -mer primers, the kits $C$ and D

Table 1. Distribution of selected species of genus Malus in this study and their chromosome numbers (adopted from Way et al., 1991)

\begin{tabular}{lcl}
\hline \multicolumn{1}{c}{ Species } & $\begin{array}{c}\text { Chromosome } \\
\text { number }(2 \mathrm{n})\end{array}$ & \multicolumn{1}{c}{ Distribution } \\
\hline $\begin{array}{l}\text { M. sieversii } \\
\text { M. pumila }\end{array}$ & $\begin{array}{l}\text { ? } \\
\text { M. asiatica }\end{array}$ & $\begin{array}{l}\text { North-wast China } \\
\text { Europe }\end{array}$ \\
M. baccata & 34,68 & $\begin{array}{l}\text { North and north-east } \\
\text { China, Korea }\end{array}$ \\
M. baccata var. & 34,68 & $\begin{array}{l}\text { North and north-east } \\
\text { China, Korea }\end{array}$ \\
mandshurica & & North-east China, Korea \\
M. baccata for. minor & 34 & Korea \\
M. sieboldii & 34 & Korea \\
M. floribunda & 34 & Korea, Japan \\
M. micromalus & 34 & Korea (endemic to Jeju \\
& & Island) \\
\hline
\end{tabular}

(OPC-01 to 20 and OPD-01 to 20) of Operon Technoligies (Alameda, Co.) were used. All the reactions were repeated twice and only reproducible bands were scored for analyses (Table 2).

Amplification reactions were conducted under standardized conditions in a $25 \mu \mathrm{l}$ reaction volume containing 10 $\mathrm{mM}$ Tris- $\mathrm{HCl}(\mathrm{pH} 8.8), 1.25 \mathrm{mM}$ each of dATP, dCTP, dGTP, dTTP, 5.0 pM primer, 2.5 units Taq DNA polymerase, and $25 \mathrm{ng}$ of genomic DNA. A 100 bp ladder DNA marker (Pharmacia) was used for the estimation of fragment size. The amplification products were separated by electrophoresis on $1.5 \%$ agarose gels, stained with ethidium bromide, and photographed under UV light using Alpha Image TM (Alpha Innotech Co., USA).

\section{Statistical analyses}

All RAPD bands were scored by eye and only unambiguously scored bands were used in the analyses. Because RAPDs are dominant markers, it was assumed that each band corresponded to a single character with two alleles, presence (1) or absence (0) of the band.

The following genetic parameters were calculated using a POPGENE computer program (ver. 1.31) developed by Yeh et al. [24]: the percentage of polymorphic loci $\left(P_{\mathrm{p}}\right)$, mean numbers of alleles per locus $(A)$, effective number of alleles per locus $\left(A_{\mathrm{E}}\right)$ and gene diversity $(H)$ [17].

To elucidate the organization of the variation in Malus taxa, genetic variation was examined by partitioning of the total genetic diversity $\left(H_{\mathrm{T}}\right)$ to within $\left(H_{\mathrm{S}}\right)$ and among $\left(D_{\mathrm{ST}}\right)$ taxa components using Nei's genetic diversity statistics [16]. A measure of differentiation among populations, relative to the total diversity was calculated at each locus as $G_{S T}=D_{\text {ST }} / H_{\mathrm{T}}$. Furthermore, gene flow $(N m)$ between the pairs of populations was calculated from $G_{S T}$ values by $\mathrm{Nm}$ $=0.5\left(1 / G_{\text {ST }}-1\right)$.

To elucidate the extent of genetic departure of populations from each other, Nei's genetic identity $(I)$ and genetic distance $(D)$ were calculated for each pairwise combination of populations [16].

The degree of polymorphism was quantified using Shannon's index of phenotypic diversity [3]:

$$
H_{\mathrm{O}}=-p_{i} \log p_{i}
$$

where $p_{i}$ is the frequency of a particular phenotype $i . H_{\mathrm{O}}$ can be calculated and compared for different populations [19]. Let 


$$
H_{\mathrm{POP}}=1 / \mathbf{n} \quad H_{\mathrm{O}}
$$

be the average diversity over the different populations and let

$$
H_{\mathrm{SP}}=-p \log p
$$

be the diversity calculated from the phenotypic frequencies $p$ in all populations considered together. Then the proportion of diversity present within populations, $H_{\mathrm{POP}} / H_{\mathrm{SP}}$, can be compared with that of between populations $\left(G_{S T}\right)$, $\left(H_{S P}-H_{P O P}\right) / H_{S P}$.

A phenetic relationship was constructed by the neighborjoining (NJ) method [20] using the NEIGHBOR program in PHYLIP version 3.57 [5].

\section{Results}

From the 40 decamer primers used for a preliminary RAPD analysis, seventeen primers of them produced good amplification products both in quality and variability (Table 2). Overall, 98 fragments were generated among the tested Malus array. The fragments ranged from 4-9 per primer (Fig. 1).

In a simple measure of intraspecies variability by the percentage of polymorphic bands, M. pumila showed the highest $(50.0 \%)$ (Table 3). M. micromalus exhibited the lowest

Table 2. List of decamer oligonucleotides utilized as primers, their sequences, and associated polymorphic fragments amplified in Malus taxa

\begin{tabular}{ccc}
\hline No. of primer & Sequence $\left(5^{\prime}>3^{\prime}\right)$ & No. of fragments \\
\hline OPC01 & TTCGAGCCAG & 6 \\
OPC02 & GTGAGGCGTC & 8 \\
OPC03 & GGGGGTCTTT & 6 \\
OPC05 & GATGACCGCC & 4 \\
OPC06 & GAACGGACTC & 7 \\
OPC08 & GTCCCGACGA & 4 \\
OPC10 & TGTCTGGGTG & 5 \\
OPC13 & AACCCTCGTC & 6 \\
OPC14 & TGCGTGCTTC & 3 \\
OPC17 & TTCCCCCAG & 7 \\
OPC20 & ACTTCGCCAC & 6 \\
OPD01 & ACCGCGAACG & 4 \\
OPD02 & CGACCCAACC & 8 \\
OPD05 & TGAGCGGACA & 9 \\
OPD07 & TTGGCACGGG & 3 \\
OPD11 & AGCGCCATTG & 5 \\
OPD16 & AGGGCGTAAG & 7 \\
Total & - & 98 \\
\hline
\end{tabular}

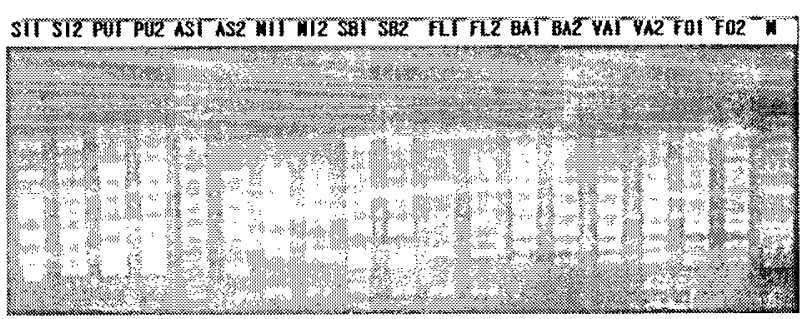

Fig. 1. RAPD profiles by OPD05 for nine Malus taxa. SI1 and SI2: M. sieversii, PU1 and PU2: M. pumila, AS1 and AS2: $M$. asiatica, MI1 and MI2: M. micromalus, SB1 and SB2: $M$. sieboldii, FL1 and FL2: $M$. floribunda, BA1 and BA2: $M$. baccata, VA1 and VA2: $M$. baccata var. mandshurica, FO1 and FO2: M. baccata for. Minor. M: marker.

variation $(34.7 \%)$. Mean number of alleles per locus $(A)$ ranged from 1.347 to 1.500 with a mean of 1.437 . The effective number of alleles per locus $(A \mathrm{e})$ ranged from 1.290 to 1.405.

The phenotypic frequency of each band was calculated and used in estimating genetic diversity $(H)$ within species. Although the typical species except two cultivated species (M. pumila and M. asiatica) were small, isolated, and patchily distributed for natural populations, they maintained a high level of genetic diversity for seventeen primers. The mean of $H$ was 0.190 across species, varying from 0.155 to 0.220 . In particular, both cultivated species, M. pumila and M. asiatica, had high expected diversity, 0.220 and 0.216 , respectively. Isolated endemic species, $M$. micromalus had the lowest (0.155).

Shannon's index of phenotypic diversity (I) of M. pumila (0.314) was the highest among all species and $M$. asiatica

Table 3. Measures of genetic variation for genus Malus. The number of polymorphic loci $(\mathrm{Np})$, percentage of polymorphism $(\mathrm{Pp})$, mean number of alleles per locus $(A)$, effective number of alleles per locus $\left(A_{\mathrm{E}}\right)$, gene diversity $(H)$, and Shannon's information index $(I)$

\begin{tabular}{lcccccc}
\hline \multicolumn{1}{c}{ Taxa } & $N \mathrm{p}$ & $\mathrm{Pp}$ & $A$ & $A_{\mathrm{E}}$ & $H$ & $I$ \\
\hline M. sieversii & 45 & 45.9 & 1.459 & 1.377 & 0.205 & 0.292 \\
M. pumila & 49 & 50.0 & 1.500 & 1.404 & 0.220 & 0.314 \\
M. asiatica & 47 & 48.0 & 1.480 & 1.405 & 0.216 & 0.307 \\
M. baccata & 45 & 45.9 & 1.459 & 1.337 & 0.186 & 0.269 \\
M. baccata var. mandshurica & 43 & 43.9 & 1.439 & 1.353 & 0.190 & 0.272 \\
M. baccata for. minor & 41 & 41.8 & 1.418 & 1.362 & 0.191 & 0.271 \\
M. sieboldii & 42 & 42.9 & 1.429 & 1.366 & 0.193 & 0.274 \\
M. floribunda & 39 & 38.8 & 1.398 & 1.319 & 0.175 & 0.250 \\
M. micromalus & 34 & 34.7 & 1.347 & 1.290 & 0.155 & 0.220 \\
Mean & 42.8 & 43.5 & 1.437 & 1.357 & 0.190 & 0.274 \\
Total (genus level) & 83 & 84.7 & 1.847 & 1.581 & 0.326 & 0.479 \\
\hline
\end{tabular}


was the second $(0.220)$.

Total genetic diversity $\left(H_{\mathrm{T}}\right)$ varied between 0.144 for $M$. micromalus and 0.207 for M. pumila (Table 4). The interlocus variation of genetic diversity $\left(H_{\mathrm{s}}\right)$ was low (0.134). On a per locus basis, the proportion of total genetic variation due to differences among species (GST) ranged from 0.101 for M. micromalus to 0.307 for $M$. baccata for. Minor with a mean of 0.240 , indicating that $24 \%$ of the total variation was found among species. An assessment of the proportion of diversity present within species, $76 \%$ of genetic variation resided within taxa. The $\mathrm{Nm}$ was estimated to be moderate (1.482).

An assessment of the proportion of diversity present within species, $H_{\mathrm{POP}} / H_{\mathrm{SP}}$, indicated that about $57.7 \%$ the total genetic diversity was among species. Thus, about $42.3 \%$ of genetic variation resided within genus (Table 5).

Genetic identity $(I)$ based on the proportion of shared fragments was used to evaluate relatedness among species.

Table 4. Estimates of genetic diversity of Malus taxa. Total genetic diversity $\left(H_{\mathrm{T}}\right)$, genetic diversity within populations $\left(H_{\mathrm{s}}\right)$ proportion of total genetic diversity partitioned among populations $\left(G_{S T}\right)$, and gene flow $(\mathrm{Nm})$

\begin{tabular}{lcccc}
\hline & $H_{\mathrm{T}}$ & $H_{\mathrm{S}}$ & $\mathrm{G}_{\mathrm{ST}}$ & $\mathrm{Nm}$ \\
\hline M. sieversii & 0.195 & 0.140 & 0.285 & 1.258 \\
M. pumila & 0.207 & 0.149 & 0.280 & 1.289 \\
M. asiatica & 0.200 & 0.144 & 0.281 & 1.282 \\
M. baccata & 0.173 & 0.129 & 0.252 & 1.482 \\
M. baccata var. mandshurica & 0.184 & 0.135 & 0.266 & 1.382 \\
M. baccata for. minor & 0.177 & 0.123 & 0.307 & 1.129 \\
M. sieboldii & 0.189 & 0.151 & 0.201 & 1.994 \\
M. floribunda & 0.166 & 0.137 & 0.175 & 2.360 \\
M. micromalus & 0.144 & 0.101 & 0.101 & 1.163 \\
Mean & 0.182 & 0.134 & 0.240 & 1.482 \\
Total (genus level) & 0.328 & 0.192 & 0.414 & 0.708 \\
\hline
\end{tabular}

Table 5. Partitioning of the genetic diversity into within and among Malus taxa by RAPD

\begin{tabular}{lcccc}
\hline \multicolumn{1}{c}{ Taxa } & $H_{\mathrm{SP}}$ & $H_{\mathrm{POP}}$ & $H_{\mathrm{POP}} / H_{\mathrm{SP}}$ & $\begin{array}{c}\left(H_{\mathrm{SP}}-H_{\mathrm{POP}}\right) \\
/ H_{\mathrm{SP}}\end{array}$ \\
\hline M. sieversii & 2.767 & 1.567 & 0.566 & 0.434 \\
M. pumila & 2.758 & 1.457 & 0.528 & 0.472 \\
M. asiatica & 2.723 & 1.558 & 0.572 & 0.428 \\
M. baccata & 2.658 & 1.536 & 0.578 & 0.422 \\
M. baccata var. mandshurica & 2.608 & 1.543 & 0.592 & 0.408 \\
M. baccata for. minor & 2.670 & 1.530 & 0.573 & 0.427 \\
M. sieboldii & 2.537 & 1.518 & 0.598 & 0.402 \\
M. floribunda & 2.441 & 1.495 & 0.612 & 0.388 \\
M. micromalus & 2.498 & 0.246 & 0.577 & 0.423 \\
Mean & 2.629 & 1.383 & 0.577 & 0.423 \\
\hline
\end{tabular}

Table 6. Genetic identity (upper diagonal) of Malus taxa and genetic distances (low diagonal) based on RAPD analysis

\begin{tabular}{cccccccccc}
\hline Taxa & M-1 & M-2 & M-3 & M-4 & M-5 & M-6 & M-7 & M-8 & M-9 \\
\hline M-1 & - & 0.985 & 0.907 & 0.806 & 0.826 & 0.793 & 0.741 & 0.756 & 0.703 \\
M-2 & 0.016 & - & 0.895 & 0.799 & 0.818 & 0.788 & 0.744 & 0.759 & 0.702 \\
M-3 & 0.097 & 0.111 & - & 0.857 & 0.795 & 0.783 & 0.787 & 0.890 & 0.754 \\
M-4 & 0.216 & 0.224 & 0.154 & - & 0.869 & 0.865 & 0.817 & 0.782 & 0.788 \\
M-5 & 0.192 & 0.201 & 0.229 & 0.140 & - & 0.925 & 0.814 & 0.788 & 0.732 \\
M-6 & 0.232 & 0.238 & 0.245 & 0.145 & 0.078 & - & 0.081 & 0.791 & 0.748 \\
M-7 & 0.300 & 0.295 & 0.240 & 0.203 & 0.206 & 0.222 & - & 0.916 & 0.884 \\
M-8 & 0.280 & 0.276 & 0.236 & 0.245 & 0.238 & 0.235 & 0.088 & - & 0.897 \\
M-9 & 0.352 & 0.354 & 0.283 & 0.238 & 0.313 & 0.290 & 0.124 & 0.108 & - \\
\hline
\end{tabular}

M-1: M. sieversii, M-2: M. pumila, M-3: $M$. asiatica, M-4: $M$. baccata, M-5: M. baccata for. Minor, M-6: M. baccata var. mandshurica, M-7: M. sieboldii, M-8: M. floribunda, M-9: $M$. micromalus.

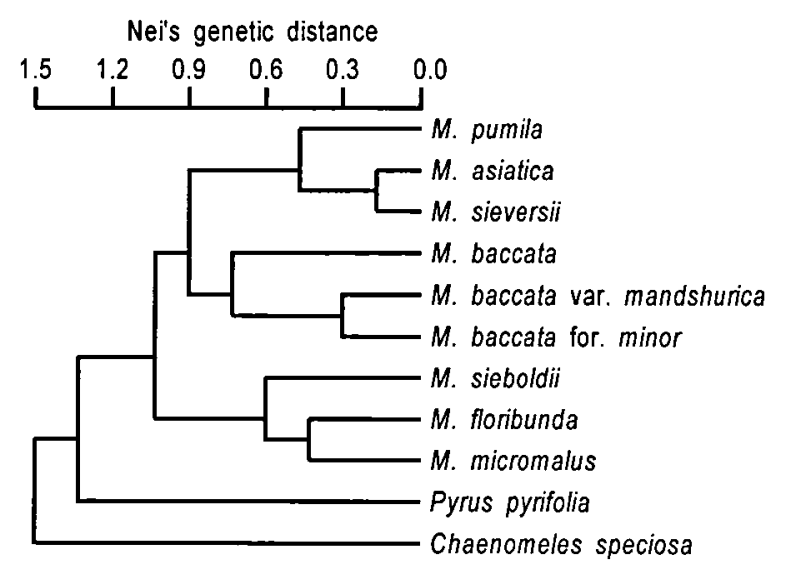

Fig. 2. A phenogram showing the relationships among nine Malus taxa and two outgroups based on data of genetic distance obtained by RAPD.

The estimate of $I$ ranged from 0.016 to 0.354 (Table 6).

Clustering of populations, using the $\mathrm{NJ}$ algorithm, was performed based on the matrix of calculated distances (Fig. 2). The phylogenic tree showed three distinct clades. One includes $M$. sieversii, $M$. pumila, and $M$. asiatica. Another includes three $M$. baccata taxa. The other includes $M$. sieboldii, $M$. floribunsa, and $M$. micromalus. One variety and one form of $M$. sieboldii were well separated each other. The tree also showed genetic differentiation among Korean species. One endemic species, M. micromalus is only isolated Jeju Island in the South Korea and is separated from $M$. sieboldii and $M$. floribunsa.

\section{Discussion}

In apple, as with other fruit tree species, two main fac- 
tors have been identified that modulate tree architecture and overall tree size [9]. The first one is the genotype, which affects branching density (e.g., related to frequency of latent buds or to as the physiological abortion of young growing points, referred to as the extinction phenomenon), proportion of short vs. long shoots (e.g., type I tree characterized by high branching density and short branches vs. type IV cultivars characterized by scare branching and longer branches), and flowering pattern (e.g., laternal vs. terminal flowering). A second factor is the root system, which has been used as an efficient although empirical means to control tree size, with variable results on flowering (i.e., dependent on the genotype) [23].

In RAPD analysis, eight species and one variety belonging to genus Malus maintain a moderate or higher than average level of genetic diversity compared with other plant species, although there is difference in methodology (e.g., dominant marker and co-dominant marker) that may preclude meaningful comparisons. For example, its genetic diversity of 0.190 is higher than that for temperate-zone species (0.146), dicots (0.136), species with a sexual reproduction mode $(0.151)$, and those with a long-lived woody habit $(0.177)[6]$.

Geographic range has been shown to be strongly associated with the level of variation maintained both within populations and at the species level. Widely distributed species tend to maintain more variation than more narrowly distributed species level [6]. For all Korean Malus taxa where the number of alleles per polymorphic loci was calculated, relatively widespread species ( $M$. sieboldii, $M$. floribunsa, and $M$. baccata) except apple species had more alleles than restricted species (M. micromalus, M. baccata var. mandshurica, M. baccata for. Minor).

The comparison of cultivated apple (M. pumila and $M$. asiatica) and wild species of genus Malus revealed that the domestication processes via artificial selection do not have eroded the levels of genetic diversity in cultivated apples. It is not in general accord with the concept that most crops show a reduced level of polymorphisms as compared to their presumed progenitors. Many studies found that wild species usually maintain higher level of polymorphism compared to cultivated species [1]. But in other species such as barley and common buckwheat, cultivated species have more genetic variability [18]. In addition, for soybean the domestication process has not eroded the levels of genetic variation [12]. It is accord that domesticated apples were hybridized with many wild species as they were spread by humans [7].

The genus of apples, Malus, belongs to the subfamily Pomoideae of the Rosaceae family. Another important fruit tree peer (Pyrus), also belongs to the same subfamily. There are over 30 primary species of apple and most can be readily hybridized $[13,22]$. The cultivated apple is probably the result of interspecific hybridization and is most appropriately called Malus $\mathrm{x}$ domestica [14]. Its primary wild ancestor is Malus sieversii whose range is centered at the border between western China and the former Soviet Union [8]. Apples are the main forest tree there and display the full range of colors, forms and tastes found in domesticated apples across the world [9]. Other species of Malus which contributed to the genetic background of the apple include: $M$. orintalis of Caucasia, $M$. sylvestris from Europe, M. baccata from Siberia, M. mandshurica from Manchuria (China) and M. prunifolia from China [7].

At present, the phenetic positions of these species shown in Fig. 1 seem to be agreed with results of morphological and distribution data. M. baccata var. mandshurica which has many hairs in leaves and petioles is sister to $M$. baccata for. minor which is hairless and is denticulate in leaf margin. One of the most striking features in this paper apple species are at least less similar to $M$. sieboldii, $M$. floribunsa, and $M$. micromalus. If RAPD data can be used identify the origin of hybrids, three species could be rule out the candidates of ancestors or rink species to reveal the history of several hybrid species.

In the present study, only $M$. sieversii was found to be closely to M. pumila and M. asiatica. Additional analysis of other species of genus Malus will hopefully further clarify the relationships among the Malus taxa.

\section{References}

1. Abo-elwafa, A. K. and M. T. Shimada. 1995. Intra- and inter-specific variations in Lens revealed by RAPD markers. Theor. Appl. Genet. 90, 335-340.

2. Barrett, S. C. H., C. G. Eckert and B. C. Husband. 1993. Evolutionary processes in aquatic plant populations. Aquat. Bot. 44, 105-145.

3. Bowman, K. D., K. Hutcheson, E. P. Odum and L. R. Shenton. 1971. Comments on the distribution of indices of diversity. Stat. Ecol. 3, 315-359.

4. Chevreau, E., Y. Lespinasse and M. Gallet. 1985. Inheritance of pollen enzymes and polyploidy origin of apple (Malus x domestica Borkh.). Theor. Appl. Genet. 71, 
268-277.

5. Felsenstein, J. 1993. PHYLIP (Phylogeny Inference Package) Version 3.5s. Distributed by the Author. Department of Genetics, Univ. of Washington, Seattle.

6. Hamrick, J. L. and M. J. W. Godt. 1989. Allozyme diversity in plant species, pp. 304-319, In Brown, A.H.D. M.T., A.L. Clegg, Kahler and B.S. Weir (eds.), Plant Population Genetics, Breeding and Genetic Resources, Sinauer, Sunderland, MA.

7. Hancock, J. F. 2003. Plant Evolution and the Origin of Crop Species. pp. 313, $2^{\text {nd }}$ eds, CABI Publishing, Wallingford.

8. Harris, S. A., J. P. Robinson and B. E. Junipae. 2002. Genetic clues to the origin of apples. Trends in Genetics 18, 426-430.

9. Hokanson, S. C., J. R. McFerson, P. L. Forsline, W. F. Lamboy, J. J. Luby, A. D. Djangalieb and H. S. Aldwinckle. 1997. Collecting and managing wild Malus germplasm in its center of diversity. HortScience $\mathbf{3 2}$, 173-176.

10. Janick, J., J. N. Cummins, S. K. Brown and M. Hermmat. 1996. Apples, pp. 1-79, In Janick, J. and J.N. Moore (eds.), Fruit Breeding, Vol. 1. Tree and Nut Fruits. John Wiley \& Sons.

11. Jung, Y. H. and M. Y. Oh. 2005. Phylogenetic relationships of Prunus (Rosaceae) in Korea and Japan inferred from chloroplast DNA sequences. Korean J. Genetics 27, 279-288.

12. Kiang, Y. T. and M. B. Gorman. 1983. Soybean, pp. 295-328, In Tankley, S.D. and T.J. Orton (eds.), Isozymes in Plant Genetics and Breeding, Part A, Elsevier, Amsterdam.

13. Korban, S. S. 1986. Interspecific hybridization in Malus. HortScience 21, 41-48.

14. Korban, S. S. and R. M. Skirvin. 1984. Nomenclature of the cultivated apple. HortScience 19, 177-180.

15. Lauri, P. L., K. Maguylo and C. Trottier. 2006.
Architecture and size relations: an essay on the apple (Malus x domestica, Rosaceae) tree. Am. J. Bot. 93, 357-368.

16. Nei, M. 1973. Analysis of gene diversity in subdivided populations. Proc. Natl. Acad. Sci. USA. 70, 3321-3323.

17. Nei, M. and W. H. Li. 1979. Mathematical model for studying genetical variation in terms of restriction endonucleases. Proc. Natl. Acad. Sci. USA. 74, 5267-5273.

18. Ohnishi, O. 1998. Search for the wild ancestor of buckwheat III. The wild ancestor of cultivated common buckwheat, and of tatary buckwheat. Econ. Bot. 52, 123-133.

19. Paul, S. P., F. N. Wachira, W. Powell and R. Waugh. 1997. Diversity and genetic differentiation among populations of Indian and Kenyan tea (Camellia sinensis (L.) O. Kuntze) revealed by AFLP markers, Theor. Appl. Genet. 94, 255-263.

20. Saitou, N. and M. Nei. 1987. The neighbor-joining method: A new method for reconstructing phylogenetic trees. Mol. Biol. Evol. 4, 406-425.

21. Veidenberg, A. E., N. R. Gaziyan and K. E. Yanes. 1977. Genetic specificity of isozymes in apple. Refertionye Zhur. 5, 256.

22. Way, R. D., H. S. Aldwincle, R. C. Lamb, A. Rejman, S. Sansavini, T. Shen, R. Watkins, M. N. Weswood and Y. Yoshida. 1991. Apples, pp. 1-66. In Moore, J.N. and Ballington, J.R. (eds), Genetic resources in temperate fruit and nut crops. International Society of Horticultural Science, Wageningen.

23. Webster, A. D., V. H. Oehl, J. E. Jackon and O. P. Jones, 1985. The orchard establishment, growth and precocity of four micropropagated apple scin cultivars. J. Horti. Sci. 60, 169-180.

24. Yeh, F. C., R. C. Yang and T. Boyle. 1999. POPGENE Version 1.31, Microsoft Windows-based Freeware for Population Genetic Analysis. University of Alberta, Alberta.

\title{
초록 : RAPD를 이용한 능금속 식물종의 계통관계와 유전적 다양성
}

\author{
허 만 규* \\ (동의대학교 분자생물학과)
}

능금속(Malus) 식물은 다년생 목본으로 국내에는 약 8종이 있다. 이 속에 있는 사과(M. pumila)는 경제적 중요 작물로 그 기원은 서중국의 야생종 M. sieversii일 것으로 추정되고 있다. 우리나라에 자생하는 Malus내 모든 분류 군과 중국의 M. sieversii를 RAPD로 분석하였다. 재배종이 높은 다양성을 나타낸 반면 제주아그배나무가 가장 낮은 다양성을 나타내었다. 재배종이 야생종보다 유전적 다양도가 더 높게 나타나 재배화 과정에서 여러 종과 교잡이 일어나 많은 유전자가 침투된 것이라는 보고를 뒷받침한다. 이 속은 M. sieversii를 포함한 사과나무, 능금 나무가 같은 분지군을 형성하였고, 개아그배나무 또는 제주아그배나무(Malus micromalus), 아그배나무(Malus sieboldii), 꽃아그배나무(Malus floribunda)가 같은 분지군, 야광나무(Malus baccata), 개야광나무(Malus baccata for. minor), 털야광나무(Malus baccata var. mandshurica)가 같은 분지군을 형성하였다. 한국내 재배종 사과와 능금이 국 내 자생종 능금속에서 진화나 분지한 것은 아닌 것으로 판명되었고 오히려 중국 야생종이 그 기원의 하나일 가능 성이 시사된다. 